\title{
VARIANCE COMPONENTS Of SOME QUANTITATIVE CHARACTERS IN 16 VARIETIES OF RICE (Oryza sativa L.) INFLUENCED BY DIFFERENT NITROGEN FERTILIZER LEVELS
}

\author{
Hamisu Almu1,2*, Abdulkadir Nasiru Ahmad', Adamu Uzaifa Karfi", \\ Sani Abdulkadir', Aminu Muhammad Ali', Ahmad Umar Bello', \\ and Adam Ibrahim Abdullahi ${ }^{1}$
}
${ }^{1}$ Department of Soil Science, Faculty of Agriculture Agricultural Technology, Wudil, Kano State, Nigeria
${ }^{2}$ Institute of Tropical Agriculture and Food Security, University of Putra Malaysia, Selangor, Malaysia
${ }^{3}$ Department of Soil Science, Faculty of Agriculture, Federal University Dutse, Jigawa State, Nigeria

*Correspondence: hamisualmu@gmail.com

Cite this article:

Hamisu A., Abdulkadir N.A., Adamu U.K., Sani A., Aminu M.A., Ahmad U.B., Adam I.A. (2021), Variance Components of Some Quantitative Characters in 16 Varieties of Rice (Oryza sativa L.) influenced by Different Nitrogen Fertilizer Levels. African Journal of Agriculture and Food Science 4(2), 13-25. DOI: 10.52589/AJAFSDNEBFWA5.

\section{Manuscript History}

Received: 7 April 2021

Accepted: 28 April 2021

Published: 7 May 2021

Copyright $\odot 2020$ The Author(s). This is an Open Access article distributed under the terms of Creative Commons AttributionNonCommercial-NoDerivatives 4.0 International (CC BY-NC-ND 4.0 ), which permits anyone to share, use, reproduce and redistribute in any medium, provided the original author and source are credited.

\begin{abstract}
Heritability and phenotypic estimates of some quantitative traits and its influence on different nitrogen fertilizer levels give the room for recombinants which become a prerequisite for any breeding study. Genetic variation in quantitative traits for the development of a new variety of crop plant with different nitrogen fertilizer levels. Based on this background, the study was conducted in order to evaluate the quantitative traits from advanced blast-resistant rice varieties in order to establish relationship between yield and yield components using genetic variances. To achieve this objective, two field studies were carried out in Malaysia during the cropping season 2017/2018. Sixteen advanced blast-resistant rice genotypes were studied in order to find out phenotypic correlation and heritability in some quantitative characters to determine the effect of various levels of Nitrogen fertilizer. The field experiment was conducted in a split-plot design replicated three times in a plot of $35 \times 28.5 \mathrm{~m}^{2}$. The planting distance was $25 \times 25 \mathrm{~cm}$ and the plot size was $2 \times 1.5 \mathrm{~m}^{2}$ unit for genotype in each replication. There was a highly significant variation among the genotypes in response to nitrogen levels, high PCV, GCV, heritability, relative distance and genetic advance which indicated that different quantitative traits especially tonnes per hectare (Tha), grain weight per plot (GWTPP) and kilogram per plot (kgplot) significantly influence the yield trait. Similarly, high heritability (>60\%) was observed indicating the substantial effect of additive genes more than the environmental effect. Yield per plant showed strong to low positive correlations $(r=0.99$ - 0.09) at phenotypic level for grain weight per plot (GWTPP), number of tillers per hill (NTH), number of panicle per hill (NPH) and kilogram per plot ( $\mathrm{kg} /$ plot $)$.
\end{abstract}

KEYWORDS: Phenotypic Correlation, Heritability, Nitrogen Fertilizer, Variance Components, Recombinants, Blast Resistant 


\section{INTRODUCTION}

Rice (Oryza sativa L.) is one of the most important crops and is a staple food grain for more than three and a half billion people living in the rural and urban areas of the World. Rice is cultivated in more than 163.24 million hectares, and annual world production is around 740.96 million tons (FAOSTAT, 2015). Majority of the countries in Asia are rice-producing where average consumption is higher than $80 \mathrm{~kg}$ per person per year, (Adnyanaet al., 2008). Rice, being one of the world's leading staple food crops, contributed significantly to global food security (Godfray et al., 2010). Factors of stress which hinder production and productivity such as decreasing arable land and availability of freshwater, there is also the increased labor cost together with biotic and abiotic stress factors. In addition to this, the dramatic rise in fertilizer' prices drives the quest for suitable rice cultivators which are efficient in the production of grain yields (Edgerton, 2010 and Ali et al., 2017). Nitrogen fertilizers are among factors influencing the genetic improvement of grains production in most agricultural areas (Bindraban et al., 2015). Nevertheless, the rise in grain yields needed substantial increases in nitrogen rates (Khush, 2005). Unfortunately, these improvements in nitrogen fertilizer use resulted in a well-documented deleterious environmental impact. The continued growth of the human population and the imminent threat of global climatic change therefore presents a major challenge for rising grain yields without exacerbating the deterioration of the natural environment at the same time (Timan, 2007). There is therefore an urgent need to grow crops which display improved efficiency in nitrogen use (Fageri et al., 2013). Nitrogen fertilizers had to be applied in order to correct this limitation. Availability of nitrogen to rice plants increases its productivity (Fageriet al., 2013). It also increases the shoot dry matter, grain harvest index and many parameters that are positively associated with the grain yield (Fageria et al., 2011). Almost every farmer has the ability to use a costly $\mathrm{N}$ fertilizer excess in order to get a desirable yield of rice (Saleque et al., 2004). Imbalance use of $\mathrm{N}$ fertilizer causes harm to the rice crop and decreases grain yield. The genotypes of rice also differ in their efficiency of nitrogen use (NUE) and grain yield (Fageria and Santos, 2014). Management of nitrogen is, therefore, necessary in order to increase NUE (Fageriaet al., 2013).

To understand and assess genetic diversity in plant breeding, it is important to improve crop management and improvement so that a good selection could be realised. A large amount of well-conserved genetically diverse material was recognised in rice along with genetic polymorphism. The breeders are interested to evaluate genetic diversity based on morphological traits. These traits can be inherited without either specific biochemical or molecular techniques. Nowadays, the scientific classification of the plant was based on morphological traits (Kumar, 1999, Din et al., 2010). The rice plant (Oryza sativa) shows great morphological variation, especially in growth characteristic, yield and yield components. Grain yield is controlled by several genes and is influenced by the environment (Ashfaq et al., 2012). Recognition of the relationship between grain yield and yield components is essential in order to derive an efficient selection for the improvement in characters that are good for economic development (Kumar et al., 2014).

The aim of the study was to determine the genetic variability of some quantitative characters in rice which includes yield and yield components. Hence, a promising selection and breeding for these characters is enhanced by the plentiful variation found genetically as proposed by (Idris et al., 2012, Nirmaladevi et al., 2015) 


\section{MATERIALS AND METHODS}

\section{Plant materials, location and cultural practices}

A set of thirteen advanced blast-resistant varieties of rice and three check varieties were used in this experiment (Table 1). The field trial was conducted during the rice-growing season of 2017-2018 in two different locations at two different cropping seasons (Main season and Offseason) in diverse environments across Malaysia. The first location was Seberang Perai, Penang, Malaysia (lat. $05^{\circ} 22^{\circ} \mathrm{N}$, long. $100^{\circ} 15^{\circ} \mathrm{E}, 3 \mathrm{~m}$ elevation) and the second location MADA, Kehda state, Malaysia (lat. $5^{0} 59^{\prime} \mathrm{N}$, long. $100^{\circ} 24^{\prime} \mathrm{E}, 18 \mathrm{~m}$ elevation). The trials were conducted in two cropping seasons under a different growing condition in (Main and Off seasons). Each trial represents one environment (the combination of year and location). The environment covered a wide range of conditions differing in temperature, water regimes and management conditions. The experiment was conducted whereby $30 \mathrm{~g}$ of each rice accession was placed in plastic Petri dishes which were oven-dried at $50^{\circ} \mathrm{c}$ for 24 hours to break the dormancy of the seeds. After germinating the seeds, they were transferred into a nursery for good establishment. After 21 days the seedlings were then transplanted into the main field. The experimental design was split plot design with three replications in a plot of $35 \times 28.5 \mathrm{~m}^{2}$. The planting distance of $25 \mathrm{~cm} \times 25 \mathrm{~cm}$ was maintained, and the plot size is $2 \mathrm{~m} \times 1.5 \mathrm{~m}$ unit for genotype in each replication. The optimum date for transplanting at the location was followed according to the farmer's schedule. Regular hand weeding was embarked upon to free the plants of interspecific competition. Uniform fertilizer application was applied as prescribed by Malaysian Agricultural Research and Development Institute, MARDI. Nitrogen was applied at five (5) different rates viz, $60 \mathrm{kgN}, 80 \mathrm{KgN}, 100 \mathrm{KgN}, 120 \mathrm{KgN}$ and $140 \mathrm{~kg}$ using Urea and Compound fertilizer (N.P.K Green 15:15:15), the first application was done at two weeks after sowing (WAS), second at six WAS and the third at nine weeks after sowing. Insect pests were controlled by applying Malathion and Hopper Gun insecticides which were applied at recommended rates.

\section{Table 1: List of the rice genotype used}

\begin{tabular}{ll}
\hline Genotype code number & Name of the accession \\
\hline G1 & P 411 \\
G2 & P 416 \\
G3 & P 4150 \\
G4 & P 4742 \\
G5 & MR 269 (Checked varieties) \\
G6 & P 4129 \\
G7 & P 4619 \\
G8 & P 4114 \\
G9 & P 4137 \\
G10 & P 4137 \\
G11 & P 4131 \\
G12 & P 4716 \\
G13 & P 4159 \\
G14 & M 219 (Checked varieties) \\
G15 & M 263 (Checked varieties) \\
G16 & P 4170 \\
\hline
\end{tabular}




\section{Data Collection}

Data were collected at the time of crop maturity, five rice stands/plot/genotype were sampled and recorded per each replication for all the genotypes. The list of quantitative traits of rice recorded during the period of the experiment as shown in Table 2. The data were subjected to analysis of variance (ANOVA) procedure in the statistical software package (SAS version 9.4). The treatment means were compared using the Tukey's range test $(\mathrm{p} \leq 0.05)$. To measure the observed property, five plants were selected at random from each plot at harvest. Combined analysis of variances was done from the respective mean squares into phenotypic variances, genotypic variances and environmental variances.

Table 2: List of quantitative traits of rice recorded during the period of the experiment

\begin{tabular}{|c|c|}
\hline Character & Method of Evaluation \\
\hline Plant height PHT $(\mathrm{cm})$ & Average height of from the base to the tip of last leaf \\
\hline Number of tillers per hill (NTH) & By counting the number of tillers per hill \\
\hline Number of panicle per hill (NPH) & By counting the number of panicle per hill \\
\hline Filled grains per panicle (FGPC) & By counting the number of spikelets per panicle \\
\hline Unfilled grains per panicle (UFGPC) & $\begin{array}{l}\text { By counting the number of unfilled spikelets per } \\
\text { panicle }\end{array}$ \\
\hline $\begin{array}{l}\text { Percentage filled grain per panicle } \\
\text { (PFGPC) }\end{array}$ & By counting the percentage of filled grain per panicle \\
\hline Grain weight per hill (GWTPP) (gm) & By weighing total number of grains per hill \\
\hline 1000 grain weight (0ne TGWT) (gm) & By weighing 1000 filled grains \\
\hline Kilogram per plot (kgplot) & By weighing the total filled grains per plot \\
\hline Yield per ton (Tha) & By weighing the total filled grain per hectare \\
\hline
\end{tabular}

The ratio of the genotypic variance to the phenotypic variance for each trait constitutes Broadsense heritability. The determination of the type of correlation was done using Pearson's correlation in order to find out the types of associations between the studied characters and grain yield of the rice genotypes. The phenotypic of variance $\left(\sigma^{2} \mathrm{P}\right)$ and genotypic variance $\left(\sigma^{2} g\right)$ of the observed values were separated into different components. The coefficient of variation (genetic or phenotypic) was determined by Ramachandran et al., 1982 and Genetic advance and broad-sense- heritability as proposed by Johnston et al., (1955).

\section{Statistical Analysis}

(a) Genotypic variance

$\sigma^{2} g=\underline{\mathrm{MSG}-\mathrm{MSE}}$

r

where the mean square of genotypes denoted by MSG, Means square of error denoted by MSE, number of replications denoted by $r$ 
(b) Phenotypic variance:

$$
\sigma^{2} \mathrm{P}=\sigma^{2} g+\sigma^{2} g n+\sigma^{2} e
$$

where $\sigma^{2} g$ is the genotypic variance and $\sigma^{2} e$ is the mean squares of error.

(c) Phenotypic coefficient of variance (PCV):

$$
\operatorname{PVC}(\%)=\frac{\sqrt{\delta 2} p}{\underline{X}} \times 100
$$

where $\sigma^{2} p$ is the phenotypic variance and $\underline{X}$ is the mean of character.

(d) Genotypic coefficient of variance (GCV):

$$
\operatorname{GCV}(\%)=\underline{\sqrt{ } \delta 2} \mathrm{~g}
$$

\section{$\underline{X}$}

Where $\sigma^{2} g$ is the genotypic variance and $\underline{X}$ is the mean of the character

(e) Heritability (broad sense)

$$
\begin{gathered}
H^{2} B=\underline{\sigma^{2} g} \times 100 \\
\sigma^{2} p
\end{gathered}
$$

Where $\sigma^{2} g$ is the genotypic variance and $\sigma^{2} p$ is the phenotypic variance.

(f) Expected genetic advance (GA):

$\mathrm{GA}(\%)=K \times \sigma^{2} p \times h^{2} B \times 100$

GA is a percent of the mean assuming selection of the superior $5 \%$ of genotypes:

$\mathrm{GA}(\%)=K \underline{\sqrt{ } \sigma^{2} p} \times h^{2} B \times 100$

$$
\bar{x}
$$

where $K$ is a constant (selection differential $=2.06$ at $5 \%$ ), $\sqrt{ } \sigma^{2} p / X$ is the phenotypic standard deviation, $h^{2} B$ is the heritability, and $X$ is the mean of character. It is categorised as low (0$10 \%)$, moderate $(10-20 \%)$ and high ( $20 \%$ and above). 


\section{RESULTS}

\section{Sum of Squares of Variation}

There were significant differences $(\mathrm{p} \leq 0.01)$ among the rice genotypes, environments, nitrogen and genotype by environment (the combination of genotype and environment) as presented in Table 3a. The height of the rice plant was from ground level up to the base of fully opened flag leaf, it was measured in centimetres and average recorded. The highest total sum of squares measured by percentage variation was environments (locations) and genotype by nitrogen by environments $59 \%$ and $4 \%$ followed by the environment by genotype $2 \%$, then followed by genotypes and genotypes by environment each having $2 \%$ and $2 \%$ respectively. The variation of nitrogen was $2 \%$ of the total variation. There were a lot of differences among the sources of variation to produce the total sum of variation. The error coefficient variation was $24 \%$ of the total variation.

The combined analysis also showed the variations of the various sources as shown in Table $3 \mathrm{~b}$. The source of variation was environment $30 \%$, environment by genotype $6 \%$, nitrogen by genotype $5 \%$. The variation of genotype was $4 \%$ and nitrogen $1 \%$ of the total variation. The error has a variation of $36 \%$ is the highest source of variation.

Table 3a: Pooled analysis of the two sites (Mean Squares) for 5 quantitative characters for the 16 rice genotypes

\begin{tabular}{|c|c|c|c|c|c|c|c|c|c|c|c|}
\hline & & PHT & & NTH & & NPH & & FGPC & & UFGPC & \\
\hline SOURCE & DF & MS & $\mathrm{SS} \%$ & MS & $\mathrm{SS} \%$ & MS & $\mathrm{SS} \%$ & MS & $\mathrm{SS} \%$ & MS & $\mathrm{SS} \%$ \\
\hline Rep (ENV) & 4 & $\begin{array}{l}133.06 * * \\
14517.27\end{array}$ & 1.45 & $\begin{array}{l}482.11 * * \\
11191.87\end{array}$ & 5.26 & $293.26 * *$ & 4.33 & $\begin{array}{l}572.96 \mathrm{~ns} \\
490392.03 *\end{array}$ & 0.24 & $\begin{array}{l}83.48 \mathrm{~ns} \\
10209.91 *\end{array}$ & 0.64 \\
\hline ENV & 3 & $* *$ & 59.3 & $* *$ & 45.77 & $8112.91 * *$ & 44.92 & $*$ & 76.14 & $*$ & 29.38 \\
\hline NITRO & 4 & $326.95 * *$ & 1.78 & $528.43 * *$ & 2.88 & $135.47 * *$ & 1 & $893.75 \mathrm{~ns}$ & 0.19 & 203.79ns & 0.78 \\
\hline $\begin{array}{l}\text { ENV×NITRO } \\
\text { ENV×NITRO }\end{array}$ & 12 & $84.80 * *$ & 1.39 & $86.66 *$ & 1.42 & $57.55 \mathrm{~ns}$ & 1.27 & $1186.92 *$ & 0.74 & $201.82 *$ & 2.32 \\
\hline ×Rep (ENV) & 32 & $68.88^{* *}$ & 3 & $30.88 \mathrm{~ns}$ & 1.35 & $42.02 *$ & 2.48 & $518.85 \mathrm{~ns}$ & 0.86 & $69.20 \mathrm{~ns}$ & 2.12 \\
\hline $\begin{array}{l}\text { Genotype } \\
\text { ENV } x\end{array}$ & 15 & 83.69 ** & 1.71 & $97.24 * *$ & 1.99 & $78.05^{* *}$ & 2.16 & $3436.15^{* *}$ & 2.67 & $162.29 *$ & 2.33 \\
\hline $\begin{array}{l}\text { Genotype } \\
\text { NITRO } \times\end{array}$ & 45 & $36.10 \mathrm{~ns}$ & 2.21 & $109.60 * *$ & 6.72 & $106.42 * *$ & 8.84 & $853.65 * *$ & 1.99 & $111.76 \mathrm{~ns}$ & 4.82 \\
\hline $\begin{array}{l}\text { Genotype } \\
\text { ENV×NITRO }\end{array}$ & 60 & $47.32 * *$ & 3.87 & $30.27 \mathrm{~ns}$ & 2.48 & $18.76 \mathrm{~ns}$ & 2.08 & $509.99 \mathrm{~ns}$ & 1.59 & $92.73 \mathrm{~ns}$ & 5.34 \\
\hline ×Genotype & 180 & $23.72 \mathrm{~ns}$ & 5.81 & $31.88 \mathrm{~ns}$ & 7.82 & $22.84 \mathrm{~ns}$ & 7.59 & 413.69ns & 3.85 & $85.48 \mathrm{~ns}$ & 14.76 \\
\hline Error & 599 & $23.89 * *$ & 19.48 & $29.64 * *$ & 24.21 & $22.84 * *$ & 25.21 & $378.31 * *$ & 11.73 & $65.27 * *$ & 37.5 \\
\hline
\end{tabular}

*Significantly at 0.05 , ** highly Significantly at 0.01, ns; Not significant, PHT; plant height, NTH; Number of tillers per hill, NPH; Number of panicle per hill, FGPC; Filled grain per panicle, UFGPC; Unfilled grain per panicle, ENV; Environment(location), NITRO; Nitrogen, ENV $\times$ NIRO; Environment by Nitrogen,ENV×Genotype, NITRO $\times$ Genotype 
Table 3b: Pooled Analysis of two sites (Mean Squares) for 5 Quantitative Characters for the 16 Rice Genotypes

\begin{tabular}{|c|c|c|c|c|c|c|c|c|c|c|c|}
\hline & & PFGPC & & GWTPP & & oneTGWT & & kgplot & & Tha & \\
\hline SOURCE & DF & MS & $\mathrm{SS} \%$ & MS & SS $\%$ & MS & $\mathrm{SS} \%$ & MS & $\mathrm{SS} \%$ & MS & $\mathrm{SS} \%$ \\
\hline $\operatorname{Rep}(\mathrm{ENV})$ & 4 & $20.27 \mathrm{~ns}$ & 0.48 & $59650 * *$ & 2.89 & $1.20 \mathrm{~ns}$ & 0.36 & $1.33 * *$ & 2.84 & $1.33 * *$ & 2.81 \\
\hline ENV & 3 & $3431.60 * *$ & 30.32 & $4836.71 * *$ & 8.79 & $262.50 * *$ & 29.63 & $11.43 * *$ & 9.12 & $11.43 * *$ & 9.24 \\
\hline NITRO & 4 & $42.74 \mathrm{~ns}$ & 0.5 & $1809.14 * *$ & 4.38 & $32.67 * *$ & 4.92 & $3.97 * *$ & 4.23 & $3.97 * *$ & 4.22 \\
\hline ENV×NITRO & 12 & $46.10 \mathrm{~ns}$ & 1.63 & $1038.36^{* *}$ & 7.55 & $17.75^{* *}$ & 8.02 & $2.49 * *$ & 7.95 & $2.49 * *$ & 7.91 \\
\hline $\begin{array}{l}\text { ENV } \times \text { NITRO } \\
\times \text { Rep }(\text { ENV })\end{array}$ & 32 & $29.65 \mathrm{~ns}$ & 2.79 & $211.56^{*}$ & 4.1 & $0.96 \mathrm{~ns}$ & 1.17 & $0.48^{*}$ & 4.08 & $0.48^{*}$ & 4.05 \\
\hline Genotype & 15 & $101.20 * *$ & 4.47 & $619.56 * *$ & 5.63 & $46.81 * *$ & 26.42 & $1.41 * *$ & 5.61 & $1.41 * *$ & 5.69 \\
\hline ENV $\times$ Genotype & 45 & $48.19 * *$ & 6.39 & $337.83 * *$ & 9.21 & $2.32 * *$ & 3.93 & $0.78 * *$ & 9.38 & $0.78 * *$ & 9.59 \\
\hline $\begin{array}{l}\text { NITRO } \times \\
\text { Genotype }\end{array}$ & 60 & $27.12 \mathrm{~ns}$ & 4.79 & $130.10 \mathrm{~ns}$ & 4.73 & $2.13 * *$ & 4.82 & $0.29 \mathrm{~ns}$ & 4.71 & $0.29 \mathrm{~ns}$ & 4.73 \\
\hline $\begin{array}{l}\text { ENV } \times \text { NITRO } \times \\
\text { Genotype }\end{array}$ & 180 & $24.25 \mathrm{~ns}$ & & $153.71 * *$ & $16 . / 6$ & $1.46^{* *}$ & 9.9 & $0.34 * *$ & 16.43 & $0.34 * *$ & 16.33 \\
\hline Error & 599 & $20.27 * *$ & 35.75 & $96.64 * *$ & 35.79 & $0.48 * *$ & 10.74 & $0.22 * *$ & 35.46 & $0.22 * *$ & 35.24 \\
\hline
\end{tabular}

*Significantly at 0.05 , ** highly Significantly at 0.01 , ns; Not significant, PFGPC; Percentage filled grain per panicle, GWTPP; Grain weight per plot, oneTGWT; One thousand grain weight, kgplot; Kilogram per plot, Tha; Tonnes per hectare

\section{Performance of vegetative and yield component traits at harvest as affected by genotypes and Nitrogen levels}

Plant height: At harvest, the effects of tallness due to genotype and nitrogen were shown in Table $2 \mathrm{a}$, there was a significant difference in the tallness of the rice plant in relation to nitrogen $(\mathrm{p} \leq 0.05)$. The tallest rice plant was genotype 5 which showed significant plant height than genotype 4 and 12. However, the difference in the other genotypes was the same with genotype 5. The shortest plant was produced by genotype 12 and genotype 4 (Table 4 ). All the levels of nitrogen were at par. The interaction of nitrogen and genotype was not statistically different.

Number of tillers per hill: There was a statistical difference in the number of tillers per hill at harvest, these were shown in Table $2 \mathrm{a}$ below. There was a statistical difference $(\mathrm{p} \leq 0.05)$ in the number of tillers in genotype 9 (47.83) than in genotype 15 (28.29). However, genotypes 1,10 and 8 were the same with genotype 9 in the number of tillers, these were followed by genotypes 16, 14, $1211,7,6,3,4,13,2$. Genotypes 15 and 5 gave the lowest number of tillers of the rice produced. Nitrogen levels were found to be statistically different $(p \leq 0.05)$ on the number of tillers. There was a significant difference in $140 \mathrm{~N} \mathrm{~kg} / \mathrm{ha}$ compared to $60 \mathrm{~N} \mathrm{~kg} / \mathrm{ha}$ on the production of tillers. However, the difference in the number of tillers in $80 \mathrm{~N}, 100 \mathrm{~N}$ and $120 \mathrm{~N}$ were the same with $140 \mathrm{~N} \mathrm{~kg} / \mathrm{ha}$. Nitrogen level $60 \mathrm{~N}$ gave the lowest number of tillers (Table 4).

One Thousand Grain Weight: There was statistical difference $(\mathrm{p} \leq 0.05)$ in one thousand grain weight in genotypes of rice (Table 2b). There was a significant difference in genotype 16 (33.20) in terms of one thousand grain weight than genotype 3 (29.71). However, genotypes 5, 14, 9 and 15 were at par with treatment 16 . These were followed by genotype 2, 7, 11, 13, 12, $8,10,1,4$ and 6 (Table 4). The genotype that produces the least number of one thousand grains was 3 . There was a significant difference $(p \leq 0.05)$ in nitrogen levels in one thousand grain length of rice. There was a significant difference in nitrogen level $140 \mathrm{~N} \mathrm{~kg} / \mathrm{ha}(31.84)$ than in 
$120 \mathrm{~N} \mathrm{~kg} / \mathrm{ha}$ (30.49). However, the significant difference in nitrogen level $60 \mathrm{~N}$ aswas the same with $140 \mathrm{~N} \mathrm{~kg} / \mathrm{ha}$. These were followed by $100 \mathrm{~N}$ and $80 \mathrm{~N} \mathrm{~kg} / \mathrm{ha}$ nitrogen levels. The nitrogen level that gave the smallest number of one thousand grain weights was $120 \mathrm{~N} \mathrm{~kg} / \mathrm{ha}$.

Table 4: Performance of vegetative and yield component traits at harvest as affected by genotypes and Nitrogen levels at the two sites 2017/2018season

\begin{tabular}{lllll}
\hline Genotype & PHT & NTH & one TGWT & Tha \\
\hline 1 & $97.97 \mathrm{ab}$ & $43.52 \mathrm{ab}$ & $30.09 \mathrm{bcd}$ & $9.35 \mathrm{abc}$ \\
2 & $97.15 \mathrm{ab}$ & $34.43 \mathrm{bc}$ & $30.99 \mathrm{~b}$ & $8.34 \mathrm{c}$ \\
3 & $95.44 \mathrm{ab}$ & $38.19 \mathrm{abc}$ & $29.71 \mathrm{~d}$ & $9.89 \mathrm{abc}$ \\
4 & $92.20 \mathrm{~b}$ & $37.55 \mathrm{abc}$ & $30.07 \mathrm{bcd}$ & $9.77 \mathrm{abc}$ \\
5 & $98.19 \mathrm{a}$ & $28.4 \mathrm{c}$ & $32.85 \mathrm{a}$ & $8.39 \mathrm{c}$ \\
6 & $92.47 \mathrm{ab}$ & $39.21 \mathrm{abc}$ & $29.90 \mathrm{~cd}$ & $10.21 \mathrm{abc}$ \\
7 & $95.41 \mathrm{ab}$ & $38.56 \mathrm{abc}$ & $30.75 \mathrm{bc}$ & $9.64 \mathrm{abc}$ \\
8 & $97.09 \mathrm{ab}$ & $41.29 \mathrm{ab}$ & $30.28 \mathrm{bcd}$ & $9.89 \mathrm{abc}$ \\
9 & $93.19 \mathrm{ab}$ & $47.83 \mathrm{a}$ & $32.76 \mathrm{a}$ & $11.98 \mathrm{a}$ \\
10 & $96.95 \mathrm{ab}$ & $41.45 \mathrm{ab}$ & $30.21 \mathrm{bc}$ & $8.35 \mathrm{c}$ \\
11 & $92.51 \mathrm{ab}$ & $39.73 \mathrm{ab}$ & $30.67 \mathrm{bcd}$ & $9.70 \mathrm{abc}$ \\
12 & $92.07 \mathrm{ab}$ & $40.25 \mathrm{ab}$ & $30.50 \mathrm{bcd}$ & $10.26 \mathrm{abc}$ \\
13 & $93.77 \mathrm{ab}$ & $35.62 \mathrm{bc}$ & $32.62 \mathrm{bcd}$ & $8.89 \mathrm{bc}$ \\
14 & $94.84 \mathrm{ab}$ & $40.59 \mathrm{ab}$ & $32.82 \mathrm{a}$ & $10.99 \mathrm{abc}$ \\
15 & $97.21 \mathrm{ab}$ & $28.29 \mathrm{c}$ & $32.76 \mathrm{a}$ & $8.20 \mathrm{c}$ \\
16 & $93.04 \mathrm{ab}$ & $40.89 \mathrm{ab}$ & $33.30 \mathrm{a}$ & $11.62 \mathrm{ab}$ \\
SE & 0.33 & 0.67 & 0.10 & 0.18 \\
\hline Nitrogen (kg/ha) & & & & \\
\hline $60 \mathrm{~N}$ & $94.03 \mathrm{a}$ & $35.69 \mathrm{~b}$ & $31.44 \mathrm{ab}$ & $8.52 \mathrm{~b}$ \\
$80 \mathrm{~N}$ & $94.81 \mathrm{a}$ & $37.13 \mathrm{ab}$ & $30.86 \mathrm{~cd}$ & $8.99 \mathrm{~b}$ \\
$100 \mathrm{~N}$ & $94.81 \mathrm{a}$ & $39.44 \mathrm{ab}$ & $31.03 \mathrm{bc}$ & $10.39 \mathrm{a}$ \\
$120 \mathrm{~N}$ & $93.60 \mathrm{a}$ & $38.59 \mathrm{ab}$ & $30.49 \mathrm{~d}$ & $9.76 \mathrm{ab}$ \\
$140 \mathrm{~N}$ & $96.04 \mathrm{a}$ & $41.59 \mathrm{a}$ & $31.84 \mathrm{a}$ & $10.92 \mathrm{a}$ \\
\hline SE & 0.33 & 0.67 & 0.10 & 0.18 \\
\hline
\end{tabular}

Means followed by the same letter(s) within the same column and treatment are not significantly different using Tukey Grouping PHT; Plant height, NTH; Number of tillers per hill, one TGWT; One thousand grain weight, Tha; Tonnes per hectare

Tonnes per Hectare: There was the statistical difference $(p \leq 0.05)$ in the genotypes in tonnes per hectare obtained from the rice genotypes (Table $2 b)$. There was a significant difference in genotype 9 in the tonnes per plot than genotype 15 (Table 4). However, the statistical difference in genotype $16,14,12,6,8,3,4,11,7$ and 1 was similar to genotype 9 . These were followed by genotype 13, 5, 10 and 2 statistically. The genotype that gave the smallest quantity of tonnes per hectare was 15 . There was a statistical difference $(p \leq 0.05)$ in the level of nitrogen given to the rice genotypes. $140 \mathrm{~N} \mathrm{~kg} / \mathrm{ha}$ nitrogen level was significantly more than nitrogen level $60 \mathrm{~N} \mathrm{~kg} / \mathrm{ha}$, though the difference in $100 \mathrm{~N}$ was at par. However, nitrogen level $120 \mathrm{~N} \mathrm{~kg} / \mathrm{ha}$ was statistically the same with level $140 \mathrm{~N} \mathrm{~kg} / \mathrm{ha}$. These were followed by a nitrogen level of $80 \mathrm{~N}$ $\mathrm{kg} / \mathrm{ha}$. The least nitrogen level that gave the least tonnes per hectare. 
The genotypic variance, environmental variance, genotypic coefficient of variation, phenotypic coefficient of variation and Broad-sense heritability, relative distance and genetic advance were high and low which is a symptom of high genetic variability and these propose a significant interest in the selection for most of the traits.

In this study, most of the growth traits showed moderate PCV compared to yield and yield component traits. However, lower PCV belonged to plant height (4.26\%) while GWTPP $(22.3 \%)$ was recorded as a higher value. Also NTH, NPH, kgplot and Tha recorded moderate PCV while the FGPC, PFGPC and oneTGW gave lower PCV. UFGPC gave higher PCV. Moderate GCV were recorded in NTH, NPH and GWTPP while PHT, FGPC, UFGPC, PFGPC, oneTGWT, kgplot and Tha recorded lower GCV. Broad sense heritability ranged PHT, GWTPP, yield (Tha), having the highest value $(77.66 \%, 71.81 \%$ and $62.98 \%$ respectively) while NTH, NPH, FGPC, PFGPC, oneTGWT and Tha has been moderate in heritability while UFGPC and kg plot showed low heritability (Table 5).

Simple phenotypic correlation coefficients for the traits studied using SAS software (version 9.4) are shown in Table 6. Yield per plant showed moderately positive correlations $(r=0.99$ 0.09 ) at the phenotypic level for GWTPP, NTH, NPH and kg/plot. Other correlation coefficients between pairs of traits that are of some interest to the breeders are shown in Table 6.

Table 5: Phenotypic variation, genotypic variation, Heritability, Phenotypic Coefficient of Variation, Genotypic Variation and Genetic Advance of the combined analysis of variances

\begin{tabular}{|c|c|c|c|c|c|c|c|c|c|}
\hline \multirow{2}{*}{ Character } & \multirow[t]{2}{*}{ Mean } & \multirow[b]{2}{*}{$\begin{array}{c}\text { Phenotypic } \\
\text { variation }\end{array}$} & \multirow[b]{2}{*}{$\begin{array}{c}\text { Genotypic } \\
\text { variation }\end{array}$} & \multirow[b]{2}{*}{$\begin{array}{c}\text { Environmental } \\
\text { variances }\end{array}$} & \multirow[b]{2}{*}{$\begin{array}{c}\text { Heritability } \\
\%\end{array}$} & \multirow{2}{*}{\multicolumn{2}{|c|}{$\begin{array}{cc}\text { Ph. } & \text { Ge Coef. } \\
\text { Coef. } \% & \% \\
\text { variation variation }\end{array}$}} & \multirow[b]{2}{*}{$\mathrm{RD}$} & \multirow[b]{2}{*}{ GA } \\
\hline & & & & & & & & & \\
\hline PHT & 94.65 & 16.29 & 12.65 & 11.31 & 77.66 & 4.26 & 3.76 & 22.34 & 6.82 \\
\hline NTH & 38.49 & 56.47 & 32.82 & 36.24 & 52.45 & 19.52 & 14.88 & 41.88 & 21.09 \\
\hline NPH & 36.23 & 27.4 & 14.37 & 24.77 & 58.12 & 14.43 & 10.46 & 47.55 & 17.28 \\
\hline FGPC & 186.34 & 309.73 & 183.63 & 180.76 & 59.29 & 9.44 & 7.27 & 40.71 & 11.53 \\
\hline UFGPC & 28.16 & 79.84 & 5.64 & 58.15 & 7.06 & 31.73 & 8.43 & 92.94 & 4.61 \\
\hline PFGPC & 86.91 & 10.88 & 4.57 & 6.03 & 42 & 3.8 & 2.46 & 57.99 & 3.29 \\
\hline GWTPP & 60.64 & 181.99 & 130.69 & 110.63 & 71.81 & 22.3 & 18.9 & 28.19 & 32.99 \\
\hline OneTGWT & 31.14 & 2.04 & 1.08 & 0.32 & 52.94 & 4.6 & 3.34 & 47.06 & 5.02 \\
\hline kgplot & 2.91 & 0.209 & 0.06 & 0.056 & 28.7 & 15.71 & 8.42 & 71.29 & 9.29 \\
\hline Tha & 9.7 & 2.62 & 1.65 & 0.9 & 62.98 & 16.78 & 13.24 & 37.02 & 21.67 \\
\hline
\end{tabular}

PHT; Plant height; NTH; Number of tillers per hill; NPH; Number of panicle per hill, FGPC; Filled grain per panicle, UFGPC; Unfilled grain per panicle, GWTPP; Grain weight per plot, oneTGWT; One thousand grain weight, kgplot; Kilogram per plot, Tha; Tonnes per hectare, $\mathrm{Ph}$. Coef. \% variation; Percentage phenotypic coefficient of variation, Ge. Coef. \% variation, Percentage genotypic coefficient variation, RD; Relative distance, GA; Genetic advance 
Table 6: Pearson Correlation Coefficient of Phenotypic Relationship among the Investigated Traits in 16 Rice Genotypes

\begin{tabular}{|c|c|c|c|c|c|c|c|c|}
\hline & PHT & NTH & NPH & FGPC & UFGPC PFGPC & $\begin{array}{c}\text { one } \\
\text { GWTPP TGWT }\end{array}$ & kgplot & Tha \\
\hline PHT & 1 & & & & & & & \\
\hline NTH & -0.1278 & 1 & & & & & & \\
\hline NPH & -0.08202 & $\begin{array}{l}0.87196^{*} \\
*\end{array}$ & 1 & & & & & \\
\hline FGPC & -0.01157 & 0.0952 & $0.03805 n$ & 1 & & & & \\
\hline UFGPC & -0.06187 & -0.07324 & -0.05366 & 0.05618 & 1 & & & \\
\hline PFGPC & 0.04959 & 0.10053 & 0.05268 & $0.32163 * *$ & $-0.911 * * 1$ & & & \\
\hline GWTPP & -0.07656 & $\begin{array}{l}0.45414 * \\
*\end{array}$ & $0.40388 * *$ & $0.18641 *$ & -0.011860 .0817 & 1 & & \\
\hline oneTGWT & 0.07826 & -0.03422 & $-0.0539 n$ & $0.14713^{*}$ & -0.010680 .04085 & $0.19162 * 1$ & & \\
\hline kgplot & -0.08399 & $\begin{array}{l}0.46473 * \\
*\end{array}$ & $0.41203 * *$ & $0.199 *$ & -0.016120 .08938 & $0.9908^{* *} 0.1855^{*}$ & 1 & \\
\hline Tha & -0.0889 & $0.4616^{* *}$ & $0.40948^{* *}$ & $0.19589 *$ & -0.017880 .09027 & $\begin{array}{l}0.98891 * 0.18258 * \\
*\end{array}$ & $\begin{array}{l}0.99805 \\
* *\end{array}$ & 1 \\
\hline
\end{tabular}

*Significantly at $0.05, * *$ Significantly at $0.01, \mathrm{n}$; Not significant, PHT; plant height, NTH; Number of tillers per hill, NPH; Number of panicle per hill, FGPC; Filled grain per panicle, UFGPC; Unfilled grain per panicle, PFGPC; Percentage filled grain per panicle, GWTPP; Grain weight per plot, oneTGWT; One thousand grain weight, kgplot; Kilogram per plot, Tha; Tonnes s per hectare

\section{DISCUSSION}

Analysis of variance from the ANOVA Table showed that most of the traits were significant differences $(\mathrm{p} \leq 0.05)$ among genotypes and nitrogen. There was a highly significant difference $(\mathrm{p} \leq 0.01)$ and significant $(\mathrm{p} \leq 0.05)$ in genotypes and nitrogen as shown in table 2 . Wang et al., (2006) reported 95\% differentiation among 5 populations of rice by 20 morphological characteristics. There was also a highly significant difference in $(\mathrm{p} \leq 0.01)$ in 41 morphological characteristics between 81 ancestors of rice and also CV ranged from $2.0 \%$ for grain weight and 1000 grain to $22.1 \%$ for culm number (Caldo et al., 1996). There were several researchers on genetic variability who reported for grain yield traits, these include Idris et al. (2012); Nirmaladeviet al. (2015). There were significant differences $(\mathrm{P} \leq 0.05)$ in genotypes of rice and nitrogen levels in the production of rice. As presented in table 4, genotype 9 was found to be significant in NTH, one TGWT and Tha. Similar findings were reported by Oladosuet al. (2014). Application of $140 \mathrm{~N} \mathrm{~kg} / \mathrm{ha}$ gave positive response in increasing the performance of the studied rice genotypes across all locations followed by $120 \mathrm{~N} \mathrm{~kg} / \mathrm{ha}$.

High heritability for a particular trait indicates that such traits were not under control of the environment and therefore selection could be done. These include PHT, GWTPP and Tha that showed high heritability (Table 5). Low heritability indicates that a portion of the variation is influenced by the environment, therefore selection based on such traits is ineffective. Additive and non -additive (dominant and epistatic) were important to broad-sense heritability and therefore assist in estimating the inheritance of a character (Nirmaladeviet al, 2015). GA of the traits showed that it ranged from 6.82 for PHT to 32.99 for GWTPP, this indicates that effective selection can be achieved only when additive effects are sufficiently higher than the 
environmental effect. The phenotypic coefficient of variation in this study was a bit higher than the genotypic coefficient of variation, indicating that there was a little influence of environment on the expression of yield and its components (Bagatiet al., 2016). It has been shown that the effectiveness of selection depends on genetic advance (Latif et al., 2011). NTH and GWTPP recorded higher values for GA while NPH (17.28), FGPC (11.53) and Tha (11.27) showed moderate GA and PHT, UFGPC, PFGFPC, oneTGWT and kgplot showed low GA. Similar observation was observed by Seyoumet al., (2012) on rice. When a trait is heritable, it indicates a high genetic gain but this has to be high in genetic gain (that is high heritable and genetic advances are needed in subsequent generations) in order to have an improvement in rice selection. These findings agree with findings of Addissau, 2012, who reported that high genetic advance followed by high heritability in drought tolerance in Sorghum. The relative distance among traits and its quantitative assessment usually helps a breeder in choosing desirable parents for a breeding program as the selection of parents on the basis of divergence analysis would be more effective (Latif et al., 2011). RD was found to be high in kgplot, Tha, PFGPC and UFGPC and moderate in NTH, NPH, PFGPC and oneTGWT and low RD in PHT and GWTPP (Table 5).

Pearson's correlation coefficient was analysed between 10 quantitative traits among rice genotypes using SAS software (version 9.4). These were shown in Table 6. A positive correlation was found between most of the traits. Yield showed a strong positive correlation with GWTPP and kg per plot. There was a strong positive coefficient correlation between NTH and NPH. There was a strong negative coefficient of correlation between FGPC and UPGFPC. The more the filled grain per panicle the less will be the unfilled grain per panicle. The coefficient of correlation between kgplot and GWTPP was strongly positive.

\section{CONCLUSIONS}

Heritability of some quantitative characters in 16 varieties under the influence of various levels of nitrogen fertilizer was conducted at Penang, SeberanPerai, and at MADA, Kehda State in Malaysia during the 2017/2018 season. Most of the traits have responded significantly and this showed the presence of sufficient variability that can be used for selection. Therefore, high PCV, GCV, heritability, relative distance and genetic advance indicated that different traits especially Tha, GWTPP and kilogram per plot significantly influence the yield trait. Therefore, Identification of variation in different rice in quantitative characters can be changed in some respect during selection which signifies genetic variability. The identified heritable characters results in increased rice production at the highest level. PHT, NPH, one TGWT and yield were the identified heritable characters that could be considered for selection in rice improvement in terms of yield and yield components. Most researchers agree that high heritability alone is not enough; both high heritability and high genetic advance are needed for improvement in selection. 


\section{REFERENCES}

Addissu, A.G. (2012). "Heritability and genetic advance in recombi- nant inbred lines for drought tolerance and other related traits in sorghum(sorghum bicolor),"Continental Journal Agricultural Science, vol.5,pp. 1-9.

Adnyanan M.O., andMunarso,J.S., D.S. (2008). Economy Quality of rice and consumer tastes. 483-499. inF.kasryno, E pasa by AM Fagi (Eds) Indonesia's rice and rice economics, $\mathrm{R} \& \mathrm{D}$ department, Jakarta

Ali, J.; Xu, J.L.; Gao, Y.M.; Ma, X.F.; Meng, L.J.; Wang, Y.; Pang, Y.L.; Guan, Y.S.; Xu, M.R.; Revilleza, J.E.; et al., (2017). Harnessing the hidden genetic diversity for improving multiple abiotic stress tolerance in rice (Oryza sativaL.). PLoS ONE , 12, e0172515.(CrossRef)

Ashfaq M.;Khan A.S.,- Khan S.H.U., and Ahmad, R. (2012). Association of various morphological traits with yield and genetic divergence in rice (Oryza Sativa L.). International Journal of Agricultural Biology14: 55-62.

Bagati, S., Singh, A., Salgotra, R., Bhardwaj, R., Sharma, M., Rai, S., and Bhat, A. (2016). Genetic Variability, Heritability and Correlation Coefficients of Yield and its Component Traits in Basmati Rice (Oryza sativa L.). SABRAO Journal of Breeding and Genetics , 48(4), 445-452.

Caldo, R, L., Sebastian., and Hernandez, J. (1996). "Morphology-based genetic diversity analysis of ancestral lines of Philippine rice cultivars," Philippine Journal of Crop Science, vol. 21, no. 3, pp. 86-92.

Din, M. Y., Khan, M., Akmal., et al. (2010). "Linkage of morphological markers in Brassica,"Pakistan Journal of Botany, vol. 42,no. 5, pp. 2995-3000

Edgerton, M.D. (2009). Increasing crop productivity to meet global needs for feed, food, and fuel. Plant Physiol.149, 7-13. (CrossRef) (PubMed)

Fageria N.K., and Santos A.B dos. (2014). Lowland rice genotypes evaluation for nitrogen use efficiency. Journal of Plant Nutrition,37:1410-

Fageria N.K., Baligar V.C., and Jones C.A. (2011). Growth and mineral nutrition of field crops. $3^{\mathrm{a}} \mathrm{ed}$. Boca Raton, CRC Press. 560p.

Fageria N.K., Santos A.B dos., and Oliveira J.P. (2013). Nitrogen-use efficiency in lowland rice genotypes under field conditions. Communications in Soil Science and Plant Analysis, 44:2497-2506.

FAOSTAT, Statistics Division online database. (2015). Statistical database of the food and agriculture of the United nations.

Godfray, H.C.; Beddington, J.R.; Crute, I.R.; Haddad, L.; Lawrence, D.; Muir, J.F.; Pretty, J.; Robinson, S.;Thomas, S.M.; Toulmin, C. (2010). Food security: The challenge of feeding 9 billion people. Science 327, 812- 818.[CrossRef] [PubMed]

Idris A.E., Justin F.J., Dagash M.J.I., and Abuali A.I. (2012). Genetic variability and interrelationship between yield and yield components in some rice genotypes.

AmericanJournal of Experimental Biology. 2(2): 233- 239.

Johnson, H.W.,Robinson,H.F., and Comstock, R.E.(1955). Estimation of genetic and environmental variability in soybeans. Agronomy Journal 47: 314-318.

Khush, G.S (2005). "What it will take to feed 5 billion rice consumers in 2030". Plant Molecular Biology 59, 1-6

Kumar V., Koshta N., Sohgaura N.,and Koutu G.K. (2014). Genetic Evaluation of RILsPopulation for Yield and Quality Attributing Traits in Rice (Oryza sativa L.). Journal of Agricultural Technology 1(1): 43-51. 1423. 
Kumar, L.S. (1999). "DNA markers in plant improvement: an overview," Biotechnology Advances, vol. 17, no. 2-3, pp..143-182

Latif, M. A, M., RafiiYusop, M., Motiur Rahman., and Bashar Talukdar. M.R. (2011)."Microsatellite and minisatellite marker based DNA fingerprinting and genetic diversity of blast and resistant genotypes," Comptes Rendus Biologies, vol. 334,no. 4, pp. 282-289

Nirmaladevi G., Padmavathi G., Kota S., and Babu V.R. (2015). Genetic variability, heritability and correlation coefficients of grain quality characters in rice (Oryza sativa L.).SABRAO Journal of Breeding and Genetics 47(4): 424-433.

Oladosu, Y., Rafii, M.Y., Abdullah, N.;,Abdul Malek, M., Rahim, H.A., Hussin,G., Latif,M.A., and Kareem, I. (2014). Genetic Variability and Selection Criteria in Rice MutantLines as Revealed by Quantitative Traits. The Scientific World Journal vol. 2014,Article ID 190531, 12 pages,

Ramachadran, C., Peter K.V., n Gopalakrishnan,P K. (1982). Variation in selected varieties of cowpea (Vigna unguiculata [L.] Walp.). Agricultural Research Karale 1982, 18(1):94-97.

Seyoum, M., Alamerew. S., and Bantle, K. (2012). Genetic variability, heritability, correlation coefficient and path analysis for yield and yield related traits in upland rice (Oryza Sativa L.). Journal of plant sciences, 7:13-22.

Tilman, D. et al.(2007). Forecasting agriculturally driven global environmental change. Science, 292, 281-284 